\title{
SEABED MAPPING ON AUSTRALIA'S SOUTHERN MARGIN: BASELINE INFORMATION FOR SCIENCE AND MARINE MANAGEMENT
}

\author{
by H.M.J. Stagg, N.F. Exon \& P.J. Hill \\ (with one table and seven text-figures; figures 4 and 6 in colour)
}

STAGG, H.N.J., Exon, N.F. \& Hill, P.J., 2000 (31:v): Seabed mapping on Australia's southern margin: Baseline information for science andmarine management. In Banks, M.R. \& Brown, M.J. (Eds): TASMANIA AND THESOUTHERN OCEAN. Pap. Proc. R. Soc. Tasm. 133(3): 31-40. https://doi.org/10.26749/rstpp.133.2.31 ISSN 0080-4703. Australian Geological Survey Organisation, Canberra, ACT, Australia.

In ratifying the United Nations Convention on the Law of the Sea in 1994, Australia took responsibility for a marine jurisdiction that is more than 1.5 times the area of the landmass. While ownership of offshore resources provided under UNCLOS bestows certain rights (including exploitation), it also carries a range of obligations, including the protection and preservation of the marine environment. In order to fulfil these obligations, there is a key need for the acquisition and interpretation of baseline scientific information that will support the sustainable use and management of marine resources.

The mostcritical baseline information required is the detailed depth and shape of the seafloor and the nature of the shallow substrate, particula rly in high-use areas. Such information underpins the activities of virtually all government, industry and academic sectors working offshore, including petroleum and minerals, fisheries and mariculture, engineering, defence, transport, tourism and environmental management. Knowledge of the seabed is also critical for the issues of multiple sequential land use to be addressed offshore. The current state of such knowledge is extremely variable, with the highest quality 3-D seabed mapping data being available over only about $5 \%$ of the Australian marine jurisdiction.

Certain basic data sets should be available to all organisations and individuals working in the marine environment. Description and discussion of the seabed mapping component of acquiring those data sets on the southern margin of Australia form the basis of this paper. Priorities for seabed mapping are suggested, e.g. the southeastern and southwestern margins of the continent.

Key Words: seabed mapping, swath mapping, marine science, Australian southern margin, Law of the Sea, Australian marine jurisdiction, marine zone management.

\section{AUSTRALIA AND THE LAW OF THE SEA}

When Australia ratified the United Nations Convention on the Law of the Sea (UNCLOS) in 1994, it assumed the responsibility for a marine jurisdiction that is 1.5 to 2 times the area of onshore Australia (fig. 1, table 1). Within this jurisdiction (the Australian Marine Jurisdiction or AMJ), a number of zones have legal significance. Of these zones, two are particularly relevant here.

- The Australian Exclusive Economic Zone (AEEZ) extends 200 nautical miles from the Territorial Sea baselines. Within the 8.6 million $\mathrm{km}^{2}$ of this zone around Australia and its island territories, Australia has sovereign rights to explore and exploit, and conserve and manage the natural resources of the water column, the seabed and the subsoil.

- The Legal Continental Shelf includes the AEEZ and those areas which can be considered to be natural prolongations of the continent extending beyond the AEEZ. Within those areas extending beyond the AEEZ, Australia has sovereign rights over the natural resources of the seabed (including organisms attached to the seabed and the subsoil, but not over the water column. The area of the AMJ beyond the AEEZ is in the range of 3.3-3.7 million $\mathrm{km}^{2}$, or about half the area of onshore Australia.

Once a nation ratifies UNCLOS, there is then a ten-year time span to allow that nation to acquire and interpret the data that defines those areas beyond the EEZ, and submit its case to the UN Commission on the Limits of the Continental Shelf. In Australia's case, the deadline for submission is late 2004.

While ownership of offshore resources provided under UNCLOS bestows certain rights (including rights to exploit resources), it also carries a range of obligations to preserve and protect the marine environment. For a nation to be able to fulfil these obligations and also sustainably use and manage the resources, there is a key need for certain basic data sets to be available to all organisations and individuals working in the marine environment. Description and discussion of the seabed mapping component of acquiring those data sets on the southern margin of Australia form the basis of this paper, in which we will

- discuss the relevance of seabed mapping to many marine sectors;

- outline some of the technical aspects of modern seabed mapping, particularly the technique known as swathmapping;

- summarise some of the major results of seabed swathmapping on Australia's southern margin; and

- outline the priorities for future seabed mapping around Australia. 


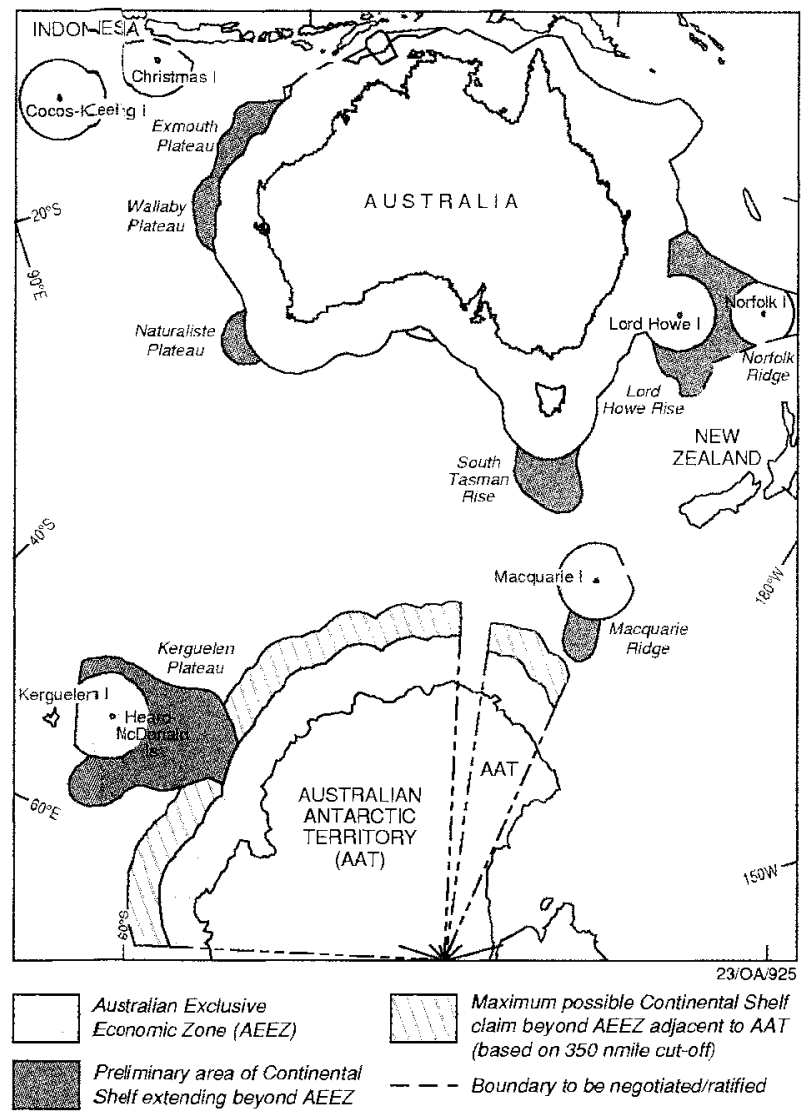

FIG. 1 - Australian jurisdictional zones under the United Nations Convention on the Law of the Sea.

TABLE 1

Approximate areas of the elements of the Australian Marine Jurisdiction

Area

$\left(\mathrm{x} 10^{6} \mathrm{~km}^{2}\right)$

Australian landmass

Continental shelf (geomorphological)

Australian Exclusive Economic Zone (AEEZ)

Australia + Lord Howe overlap

Australia + island territories

Australia + island territories + Australian

Antarctic Territory

Extended Continental Shelf beyond AEEZ

South to AAT $\left(60^{\circ} \mathrm{S}\right)$

Around AAT beyond EEZ

Total Australian Marine Jurisdiction

Australia + territories, south to AAT

Australia + territories, south to EEZ around AAT

Australia + territories + EEZ around AAT

\section{SECTORAL ISSUES IN THE AUSTRALIAN MARINE JURISDICTION}

In 1997, the Australian Geological Survey Organisation (AGSO) convened a marine geoscience planning workshop with the aim of determining national priorities for a seabed mapping program in the AMJ that incorporated the needs of most of the principal sectors working offshore (Stagg et al. 1997). The marine sectors involved were:

government bodies - including those dealing with living and non-living resource policy and management, environment, marine jurisdiction, "land" use, defence and hydrography;

industry - including companies with involvement in petroleum exploration and production, minerals exploration and production, seabed engineering (petroleum production platforms, pipelines, communications), tourism;

universities and other research organisations - including individuals and groups conducting basic research into geological processes, environment and climate change, pharmaceuticals and biotechnology.

Most of the sectors have their main interests directed at the water column, seafloor, or shallow substrate (fig. 2). Only the petroleum exploration, government policy and research sectors stand out as having a level of focus directed significantly below the seabed in the deeper crust.

Some of the more important of these sectoral interests in the seabed and shallow substrate are discussed below.

\section{Marine jurisdiction}

Definition of the outer limit of Australia's Legal Continental Shelf under UNCLOS requires detailed knowledge of the depth and shape of the seabed in deep waters (Symonds \& Willcox 1989). In several areas, the limit of Australia's jurisdictional claim, which must be submitted to the United Nations by late 2004 , will be defined on the basis of detailed bathymetry.

\section{Petroleum exploration and production}

The design and construction of petroleum production facilities (including platforms and pipelines) is strongly dependent on the depth, nature and physical properties of the seabed which must support such structures.

In the 1990s, the popular and trade press have reported several examples where inadequate technical knowledge has imposed major costs on exploration and development projects. These include the problems associated with the setting of piles for the Goodwyn gas production platform, which incurred major additional constructional costs as well as a start-up delay of several months; the dangerous exposure of a gas pipeline through cyclone-induced sediment mobility, which required remedial work at a cost of about $\$ 80$ million; and the damage sustained to a jack-up oil exploration rig which collapsed when the supporting seabed gave way while drilling was taking place in South Australian waters.

\section{Fisheries}

The habitats of many commercial fisheries are controlled by the detailed seabed topography and substrate. These fisheries, which can be very fragile components of marine ecosystems, are often poorly understood and managed. For example, the 


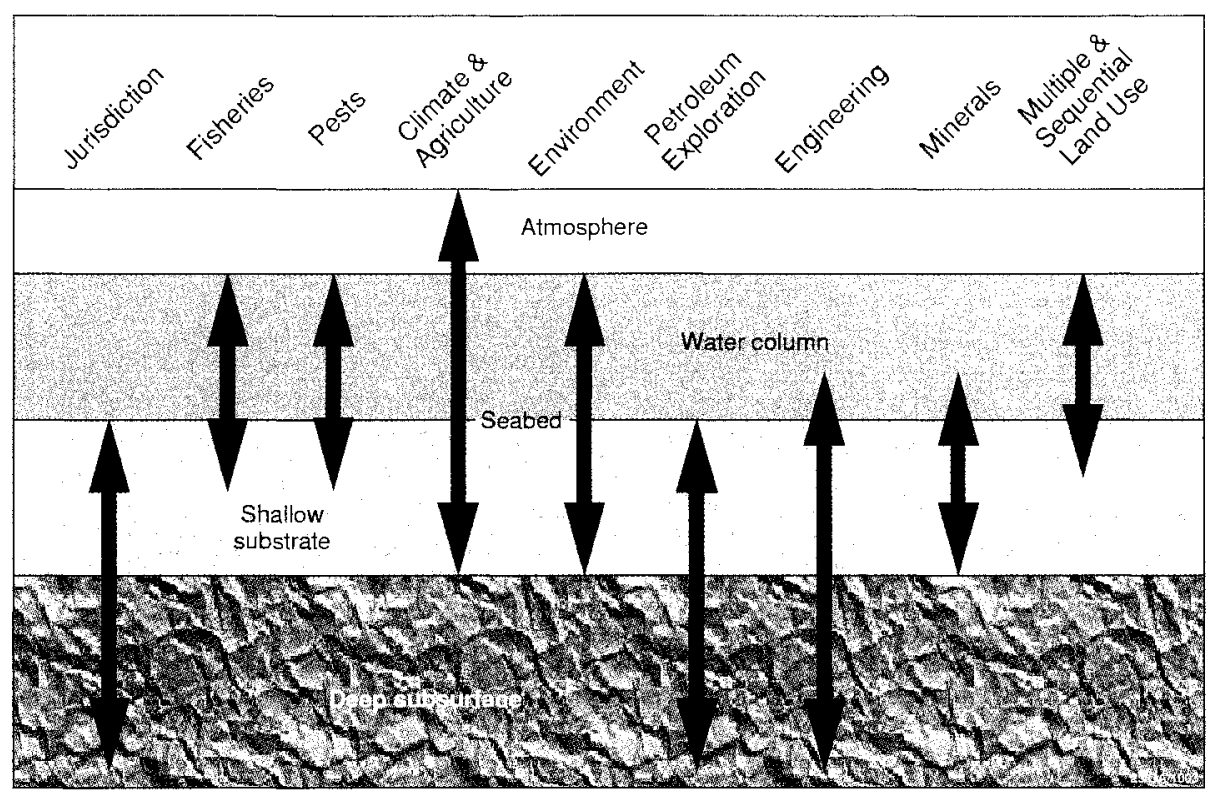

FIG. 2 - The four linked regimes of the marine environment and their relevance to key marine sectors.

existence of the valuable orange roughy fishery, south of Tasmania, is largely dependent on the presence of a particular seabed form, with associated benthic flora and fauna (Koslow \& Exon 1995, Koslow 1997).

\section{Climate change}

Geoscience can make a major contribution to society by helping agricultural planning, through the understanding of long-term climatic change. The study of sediment cores from lakes or the deep ocean can extend our knowledge of climatic variability back many millions of years (Harris et al. 1999a). The higher the sedimentation rate, the better the accuracy and definition. The study of growth phases in cores from living large colonial corals provides an exceedingly accurate record of climatic changes over the last few hundred years (Barnes \& Lough 1989). Fossil corals may eventually extend this record back a few thousand years (McCulloch et al. 1994). These studies extend the databases of climatic modellers back much further than the historical records they are more used to dealing with, thus improving their models.

The 1997 planning workshop identified the critical need for detailed mapping of the depth, shape and nature (sediment type, physical properties etc.) of the seafloor throughout the marine zones, particularly in high-use areas. These needs form the focus of this paper. The associated issue of which organisation/s should be responsible for the collation, storage and dissemination of bathymetric data and other information is also fundamental.

\section{SEABED MAPPING - TECHNICAL ISSUES}

Seabed mapping involves the integration of two basic techniques: determination of the seabed topography, through direct measurement of the water depth and the shape of the seabed, and "ground truthing" the nature of the seabed by sampling the rocks and sediments. While a considerable amount of work has been done in this field around Australia, particularly in the past 30 years, the current state of know- ledge of the seabed in much of the AMJ is comparable to the state of onshore knowledge in the 19th century.

\section{Seabed Topography}

For most of the past few hundred years, water depth and seabed topography have only been measured immediately beneath a vessel while it is underway, initially by lead-line and more recently by single-beam echo-sounder. Such mapping is necessarily slow, and the maps which are prepared from such data are frequently inaccurate, as they require the interpolation of data between tracks that may be hundreds of metres to tens of kilometres apart.

However, in the early 1990 s, three new techniques became available that have improved our knowledge of seabed topography by orders of magnitude - satellite-measured gravity and the derived predicted bathymetry; Laser Airborne Depth Sounding (LADS); and ship-board "swathmapping" (also known as multibeam mapping). While satellite-predicted bathymetric data are invaluable for defining the gross form of the seabed in the world's oceans, particularly in remote areas, the spatial resolution is limited to about $3 \mathrm{~km}$, even in the most modern data sets. LADS is being used extensively by the RAN Hydrographic Office for mapping bathymetry to depths of about $50 \mathrm{~m}$ in areas that are particularly hazardous to navigation We will not consider these techniques further in this paper.

Seabed swath-mapping can be carried out either by towed sidescan sonar systems or by hull-mounted multibeam sonar systems (fig. 3). Exon \& Hill (1999) have reviewed these systems and their relative merits. Systems of both types are capable of mapping in great detail in shallow water, or in reduced detail in deeper water. Although sidescan sonar initially produced only backscatter imagery, and multibeam systems produced only digital bathymetry, those systems are progressively becoming dual purpose.

With sidescan sonar, a sound pulse (a "ping") is emitted in a narrow beam at right angles to the ship's track (Flemming 1976). Echo arrival times and amplitudes are 
recorded to produce a line scan on a plotter, and a map of a swath of seabed is built up from successive pings as the ship moves. As the transmission geometry changes with distance across-track, a slant-range correction is usually applied to produce a plot which has been geometrically corrected. The sonar image particularly shows variations in seabed reflectivity (and hence hardness), roughness and slope. Some sidescan systems now have a bathymetric capability, with both sidescan images and bathymetry recorded simultaneously. Bathymetry across the swath is determined by measuring phase differences of acoustic arrivals on a pair of transducer arrays on each side of a towfish. The phase difference gives the direction of the backscattered return; combined with the arrival time, this yields both depth and position (Exon \& Hill 1999).

In very simplistic terms, multibeam sonar systems can be thought of as a large number of conventional single-beam echo-sounders with their beams set in a fan across-track (Hill et al. 1995). Multibeam systems have transmitting and receiving transducer arrays mounted at right angles on the hull, with the transmit array(s) aligned along the foreaft axis of the ship. The transmit beam is narrow alongship and wide athwartships. Individual receivers (162, in the case of the Simrad EM12D shown in fig. 3), which have a narrow athwartships focus, span the transmit sector, so that each received beam has a small footprint (sampling area) on the seafloor. The beams are electronically stabilised to counter roll and pitch of the ship. Detection of the seabed in the weak signal from the outer beams is achieved by comparing the phase of the returns at the two rows of transducers in the receive array. Seabed backscatter images can also be produced from the beam-formed signals of a multibeam system, and these can be directly superimposed on bathymetric contour maps (Hill et al. 1995).

One of the strengths of swath-mapping systems is that the technique can be used in the full range of water depths from a few metres to the deepest bathyal depths. Shallowwater systems typically transmit at frequencies of more than $100 \mathrm{KHz}$ and can be installed on vessels of only $10 \mathrm{~m}$ length, while deep-water systems transmit at around $12 \mathrm{KHz}$ and are typically installed on ocean-going research vessels. The "footprint" and swath width of shallow and deepwater systems show similar variations, with the footprint ranging from less than a metre square to $50 \mathrm{~m}^{2}$ or greater, and the swath width ranging from a few tens of metres to as much as $20 \mathrm{~km}$.

Systematic swath-mapping is a powerful tool for addressing both ancient and modern geological processes. Where the surficial sediment cover is thin, swath-mapping can image strata that crop out at the seabed and, hence, reveal the "tectonic grain" and the distribution of structures within and adjacent to a sedimentary basin. Such information can provide framework information of fundamental importance to hydrocarbon exploration and complements the relatively widely spaced seismic profiles which are normally the prime source of tectonic information (Gardner et al. 1991). Where the surficial sediments are relatively thick, analysis of bathymetric and back-scatter data can provide a detailed picture of the distribution and reflectance of modern sediments, and hence of the oceanographic and geologic conditions that have produced this distribution. When ground-truthed by seabed cores, this information can be important to the production and development of Australia's offshore hydrocarbon resources,

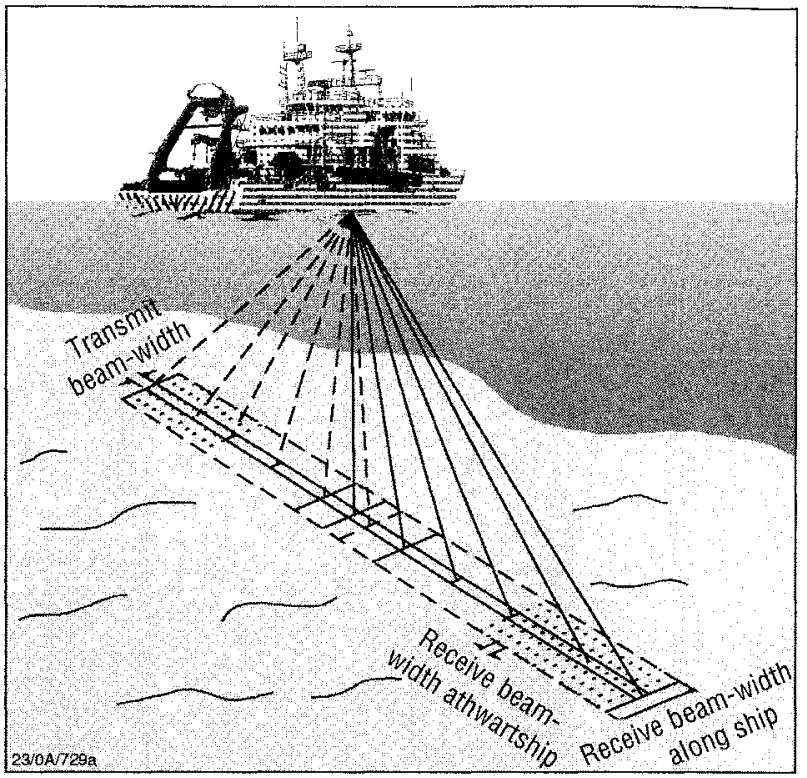

FIG. 3 - Schematic of Simrad EM12D hull-mounted multibeam swath-mapping system showing the acoustic beam configuration (after Hill et al. 1995).

to future offshore minerals mining (including construction materiais) and in the mapping of benthic habitats.

An important issue with regard to seabed swath-mapping is that of the large volumes of data that are rapidly acquired, and their access and archiving. Typically, a modern swathmapping system acquires at least a gigabyte of data per day of surveying. While post-processing reduces this data volume, the reduction is only of the order of about $50 \%$.

\section{Seabed Sampling}

The second component of a seabed mapping program is the ground-truthing of the sonar images through sampling of the shallow substrate. A large amount of seabed sampling has been carried out in the past 30 years by a number of organisations, including AGSO, RAN Hydrographic Service, universities and industry.

While a large amount of sediment data has been acquired, it is only in the past few years that serious attempts have been made to assemble the information in a form that could be accessible to a national seabed mapping program. Development of the AUSEABED database by the Ocean Sciences Institute (Jenkins \& Searle 1997, for description; Jenkins 1997, for maps) and AGSO's MARS database are attempts to collate the available information into a form that is accessible by modern technology. However, there is currently no national sample repository (or network of repositories), which means that it is difficult, in many cases, to access the original samples.

The majority of the vast number of seabed samples that have been collected have only sampled the shallowest few metres of sediment. In fact, many of the samples collected by the RAN Hydrographic Service have only come from the shallowest few centimetres. Sampling below these surficial depths (say, below $5 \mathrm{~m}$ ) requires more sophisticated techniques than those which are generally available. Cores up to $40 \mathrm{~m}$ long can be taken in soft deep-sea sediments by 
giant pi ston corers, such as those on the French research vessel Maizon Dufresne, which took such cores on the South Tasman Rise and elsewhere in 1997 (Nees et al. 1998). Such coring systems are of little value where hard rocks outcrop at the seabed or are shallowly buried.

The Ocean Drilling Program (ODP 1996) and its predecessor the Deep Sea Drilling Project (DSDP) are capable of taking continuous or near-continuous cores in soft sediments, sedimentary rocks and igneous rocks in almost any water depth greater than $100 \mathrm{~m}$, down to $2000 \mathrm{~m}$ below the seabed, although few holes have yet gone deeper than $1500 \mathrm{~m}$. Since 1971 , a number of DSDP and ODP drilling legs have been carried out in the oceans around Australia, including DSDP Legs 21, 26, 27, 29 and 90, and ODP Legs 119 and 120 (Kerguelen Plateau and Prydz Bay), 122 and 123 (Exmouth Plateau, Gascoyne and Argo Abyssal Plains), 133 (northeast Australia), and 182 (Great Australian Bight). Further drilling legs are scheduled in 1999-2000 on the South Tasman Rise and in Prydz Bay, Antarctica. The disadvantage of this tool is that it is expensive and samples a very limited number of locations.

A consortium based at the University of Sydney has built a Portable Remotely Operated Drill (PROD). PROD is designed to recover up to $100 \mathrm{~m}$ of core from research or industry vessels in water depths of up to $2000 \mathrm{~m}$. Such a sampling technique can fill the gap between conventional gravity, piston and vibrocoring, and ODP or industry exploration drilling.

\section{EXAMPLES OF SWATH-MAPPING SURVEYS}

There have been two main phases of seabed swath-mapping around Australia since the inception of this type of work in the early 1980s. In the first phase (1983-89), combined GLORIA (ultra-long range sidescan sonar) and SeaBeam (multibeam sonar) surveys were carried out by HMAS Cook off northeastern Australia (Johnson et al. 1992), New South Wales (Jenkins \& Lawrence 1990), canyon systems south of the mouth of the Murray River (von der Borch \& Hughes Clarke 1993) and part of the southern coast of Western Australia. As the swath-mapping technique was then in its infancy, these data sets are of limited value when compared to the data which can now be acquired.

The second phase of swath-mapping commenced in 1994, when AGSO mapped $160000 \mathrm{~km}^{2}$ of seabed along $800 \mathrm{~km}$ of the Macquarie Ridge, north and south of Macquarie Island (Coffin et al. 1994). This survey used the HMR1, a towed wide-angle imaging system developed by the Hawaii Institute of Geophysics, which was deployed from the AGSO research vessel Rig Seismic. The HMRl produces high-quality side-scan imagery, but its bathymetric resolution is only about half that of modern multibeam echo-sounders.

Since the Macquarie Ridge survey, a further three surveys have been carried out in Australian waters; all of these have been carried out on foreign vessels of opportunity, and all have been focussed on the southern margin. These surveys are:

- the Tasmante survey (1994) south and west of Tasmania, using the French vessel L'Atalante (Exon et al. 1994, Hill et al. 1995, Exon \& Crawford 1997);
- the East Tasmania survey (1997), which encompassed the continental margin of Tasmania and Victoria from south of Hobart to the northern side of the Bass Canyon using the US research vessel Melville (Hill et al. 1998, Exon et al. 1999); and

- the MARGAU survey (1998) off southwest Australia using the French research vessel Marion Dufresne (Royer et al. 1998).

The major results of the Tasmante and East Tasmania surveys provided valuable examples of the quality of data which can now be produced and their multidisciplinary, cross-sectoral value. Figure 4 shows the topography of the Tasmanian region and incorporates the swath-mapping data from both of these surveys. The effect of the swathmapping data can be seen in the high degree of detail on the Tasmanian margins, on the western flank of the South Tasman Rise and east of Bass Strait.

\section{Tasmante Survey}

The Tasmante survey was carried out for AGSO with the French research vessel L'Atalante. The main aim of the survey was to map in detail the South Tasman Rise and the west Tasmanian margin and to use the results to refine our understanding of the geological framework of the region, particularly the breakup of Australia and Antarctica in the Late Cretaceous and Cainozoic. L'Atalante is equipped with a Simrad EM12D system, a 162-beam sonar system with a maximum swath coverage of $150^{\circ}$, enabling a strip of seafloor more than $20 \mathrm{~km}$ wide to be mapped at a single pass in moderate water depths.

The geological results of this survey have been discussed in a number of papers (Exon \& Hill 1999, Exon et al. 1996, 1997, Hill et al. 1995, 1997) and will not be discussed in detail here. Suffice it to say that the swath-mapping data, in conjunction with reflection seismic data that were recorded concurrently, have led to a revised and much more detailed interpretation of the geological framework of the region, including deep-water sedimentary basins that may be prospective for hydrocarbons at some stage in the future.

The value of seabed-mapping to the non-geoscience marine sectors was well illustrated by the Tasmante survey. Areas south, east and west of Tasmania are host to major demersal fisheries for orange roughy and blue grenadier. Because the fishermen seek to run their trawls just above the seabed, the high-quality Tasmante bathymetric maps of the seabed have generated a great deal of interest. Prior to the release of detailed maps of the two fisheries areas south and west of Tasmania, AGSO consulted widely with other Commonwealth agencies about conservation questions, concerning not only the fish stocks but also the organisms growing on numerous seamounts in the region. The Southeast 'Trawl Association agreed that newly discovered deeper seamounts (fig. 5) should be the subject of a fishing moratorium while research was carried out into their natural resources (Koslow \& Exon 1995), and a $370 \mathrm{~km}^{2}$ interim Commonwealth Marine Protected Area was declared. CSIRO is carrying out a three-year study of the impact of trawling on seamounts and the conservation value of the protected area. Koslow (1997) reported that the seamounts 

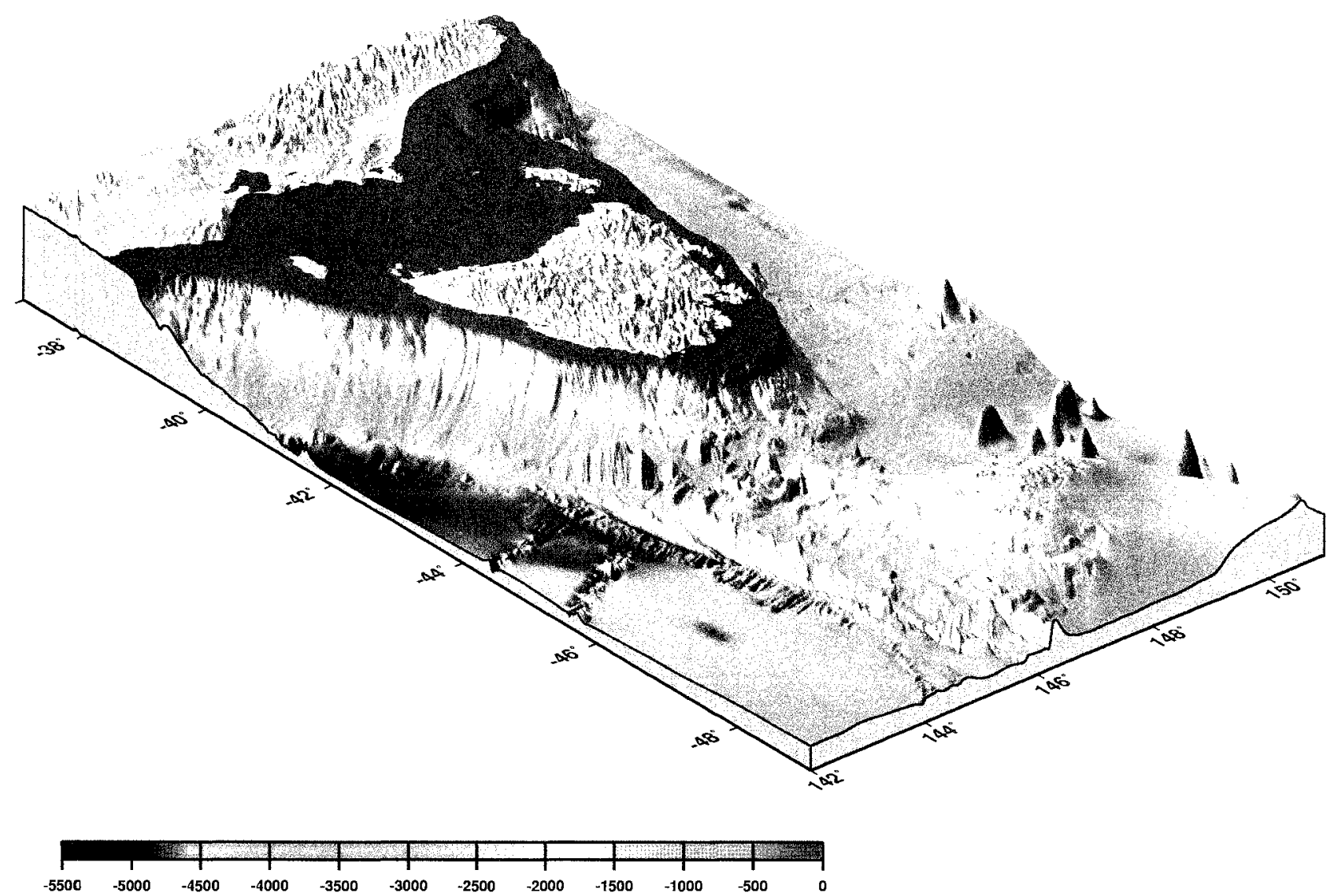

FIG. 4-Perspective view of the topography of the Tasmanian region. Regional bathymetry from the global ETOPO5 digital data set, supplemented in Bass Strait by data from the RAN Hydrographic Office. Detailed bathymetry west, south and east of Tasmania, and east of Bass Strait was recorded by swath-mapping on AGSO surveys. Note the change in resolution near the edge of the abyssal plain southwest of Tasmania where swath-mapping and ETOPO5 data have been merged.

support a diverse fauna dominated by a colonial stony coral, Solenosmilia variabilis, and that the fauna is highly endemic with numerous new species.

\section{East Tasmania Survey}

In 1997, the $85 \mathrm{~m}$ Scripps Institution of Oceanography research vessel Melville mapped the seabed on the continental margin of east Tasmania and at the eastern end of Bass Strait in a cooperative project with AGSO. The Melville is fitted with a SeaBeam 2000, a 121-beam sonar system with a swath coverage of $120^{\circ}$. The maximum swath width is about 3.4 times the water depth, and about $20000 \mathrm{~km}^{2}$ of the margin were surveyed in eight days of surveying (Hill et al. 1998).

The aims of the cruise were to determine the morphology and seabed character of selected areas, to provide data for tectonic, basin and sedimentological studies (including surveying a jarosite dumping site southeast of Hobart Harris et al. 1999b), to aid the fishing industry, and to provide critical information for future geoscience surveying. A specific objective was to map the structure of bedrock outcrop on the eastern margin of an inferred sedimentary basin beneath the upper continental slope off the Freycinet Peninsula.

Figure 6 is a perspective view to the northwest of the continental margin east of Bass Strait and illustrates the

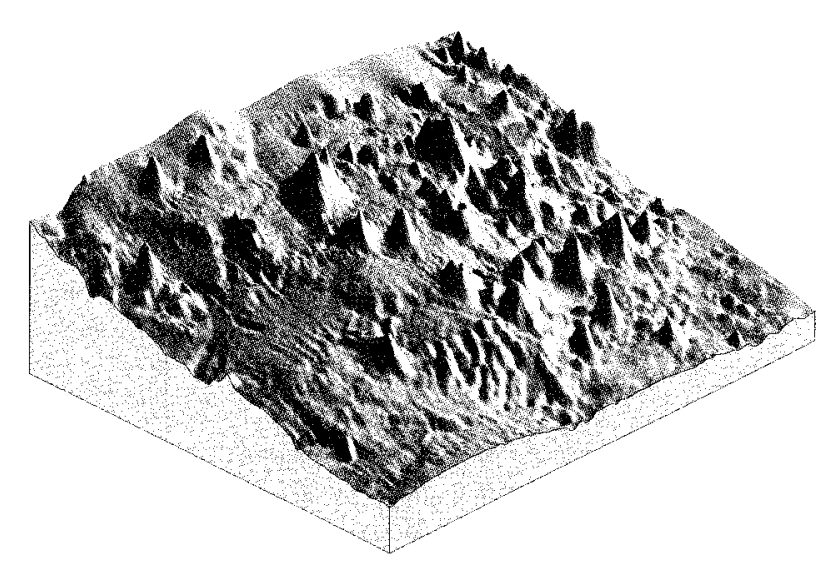

FIG. 5 - Field of seamounts on the upper continental slope, south of Tasmania recorded by swath-mapping. This image measured approximately $40 \mathrm{~km}^{2}$. These seamounts, many of which were not known prior to the swath-mapping, are found in water depths of 900-2300 m. They typically stand about $400 \mathrm{~m}$ above the adjacent seabed and are several kilometres across. The summits of some of these seamounts are the natural babitat of the adult orange roughy. 
quality of his data set. The Bass Canyon is a large embayment $100 \mathrm{~km}$ across that is floored by an axial ESEtrendin $\mathrm{g}, 10-15 \mathrm{~km}$ wide axial trough. This trough has probably acted as a conduit for clastic sediment being transported to the deep Tasman Basin since eastern Australia separated from the Lord Howe Rise at about $80 \mathrm{Ma}$ (Hill et al. 1998). The adjacent shelf beneath the eastern Bass Strait is generally flat and less than $100 \mathrm{~m}$ deep, and is covered by sandy sediments.

The shallow-water part of the survey area is significant in that it lies adjacent to oil and gas fields, such as Esso's Blackback Field being developed in the Gippsland Basin, and is alsoan important fishing ground. The seafloor here is characterised by a steep upper continental slope with closely spaced, erosional channelling (fig. 6). These channels were probably cut during glacial lowstands when abundant sediment was shed from an exposed continental shelf, eroding the slope as it was transported into the canyon. Alternatively, the gullies may have been initiated by slope failure (also during lowstands) of unconsolidated sediments, and subsequent headward erosion.

The upper slope channelling feeds into a broad semicircular amphitheatre that is $-60 \mathrm{~km}$ across and forms the upper reaches of the Bass Canyon (fig. 6). The surface of this amphitheatre is deeply incised by three major tributary canyons and a number of smaller channels. These funnel sediment from the shelf into the incised axial chasm. The larger canyons are typically $1 \mathrm{~km}$ wide and up to several hundred metres deep. The trends of the canyons show abrupt changes of direction in places, probably caused by their being deflected by faults or more resistant strata in the underlying Gippsland Basin. Abandoned meander plains adjacent to the canyons, but at higher levels, show that the path of downslope sediment flow has migrated in time. Large, high-relief canyons and ridges are found on the northern wall of the central chasm and on the steep continental slope facing the Tasman Abyssal Plain. These features are probably sculptured in basement or older sediments of the Gippsland Basin and are structurally controlled.

The axial trough is $60 \mathrm{~km}$ long and is bounded to the north and south by very steep inner canyon walls $1000 \mathrm{~m}$ high. The 7-8 km-wide floor of the trough is relatively flat and dips gently eastwards. Sediments transported down the trough debouch at about $4000 \mathrm{~m}$ depth and spread onto the abyssal plain via a network of distributary channels and levees (Hill et al. 1998).

Examination of the new topographic data in conjunction with existing seismic profiles over the Bass Canyon complex shows that submarine erosion has exposed sections of almost the entire Gippsland Basin sequence back into the Early Cretaceous strata, as well as basement rocks (Hill et al. 1998: fig. 5). Based on the new maps and images, numerous suitable dredge and core sampling sites in the canyons have been identified for geological sampling which may provide new information of value to the petroleum exploration and development industry.

\section{NATIONAL PRIORITIES FOR SEABED MAPPING}

In 1999, the Australian government released its Marine Science and Technology Plan (MSTP Working Group 1999), designed to address the marine science and technology needs for the ensuing five to 15 years. The plan contains three programs - understanding the marine environment; using and caring for the marine environment; and infrastructure for understanding and utilising the marine environment - and a total of 28 objectives within these programs. Program 1, Objective 2 was defined as

\section{To map the form and nature of the seabed of Australia's Marine Jurisdiction.}

Within this objective, several priorities and strategies were identified as relevant to a program of seabed mapping around Australia. These included

Implementation of a national swath-mapping program and seabed data digitisation program, on a priority basis determined by the regional marine planning process;

and

Develop and implement a systernatic national program to swath-map the seabed, and to sample the seabed, substrate and benthic biota of the AMJ ...

While the importance of a seabed mapping program (particularly swath-mapping) was seen as a key element of the success of the plan, it was also noted that Australia currently has very limited capacity for carrying out this style of work. In deep water, off the morphologic continental shelf, such work can currently only be undertaken using foreign vessels of opportunity, mainly of French or US registry. The RAN Hydrographic Service is currently (1999) commissioning two new ocean-going hydrographic vessels and their attendant survey motor launches which will be equipped with swath-mapping systems capable of working to depths of 300-500 m. However, these vessels are dedicated to hydrographic surveying to ensure safety of navigation, and it is likely that their availability to carry out any systematic mapping on the morphologic shelf for other purposes will be extremely limited.

As part of the process of developing the Marine Science and Technology Plan, a number of priority areas was proposed in the draft plan (MSTP Working Group 1998). To some extent, these priorities have been superseded with the release of the Australian Oceans Policy (Commonwealth of Australia 1998) and the final MSTP. We therefore suggest that the following areas (fig. 7) are the highest priorities in the short to medium term (1--5 years).

\section{Priority 1}

\section{Southeast Australia}

This region is considered to be the highest priority because the work will have direct relevance in diverse and important sectors of the marine economy. The area is also the first region of Australia for which a Regional Marine Plan will be developed, as outlined in the Oceans Policy (Commonwealth of Australia 1998). Part of this area has already been covered by the Tasmante and East Tasmania surveys referred to above. Geologic information will increase our understanding of the framework of southeast Australia, with consequent spin-offs for petroleum exploration in producing (Gippsland Basin) and frontier areas (Otway and Sydney Basins, Lord 


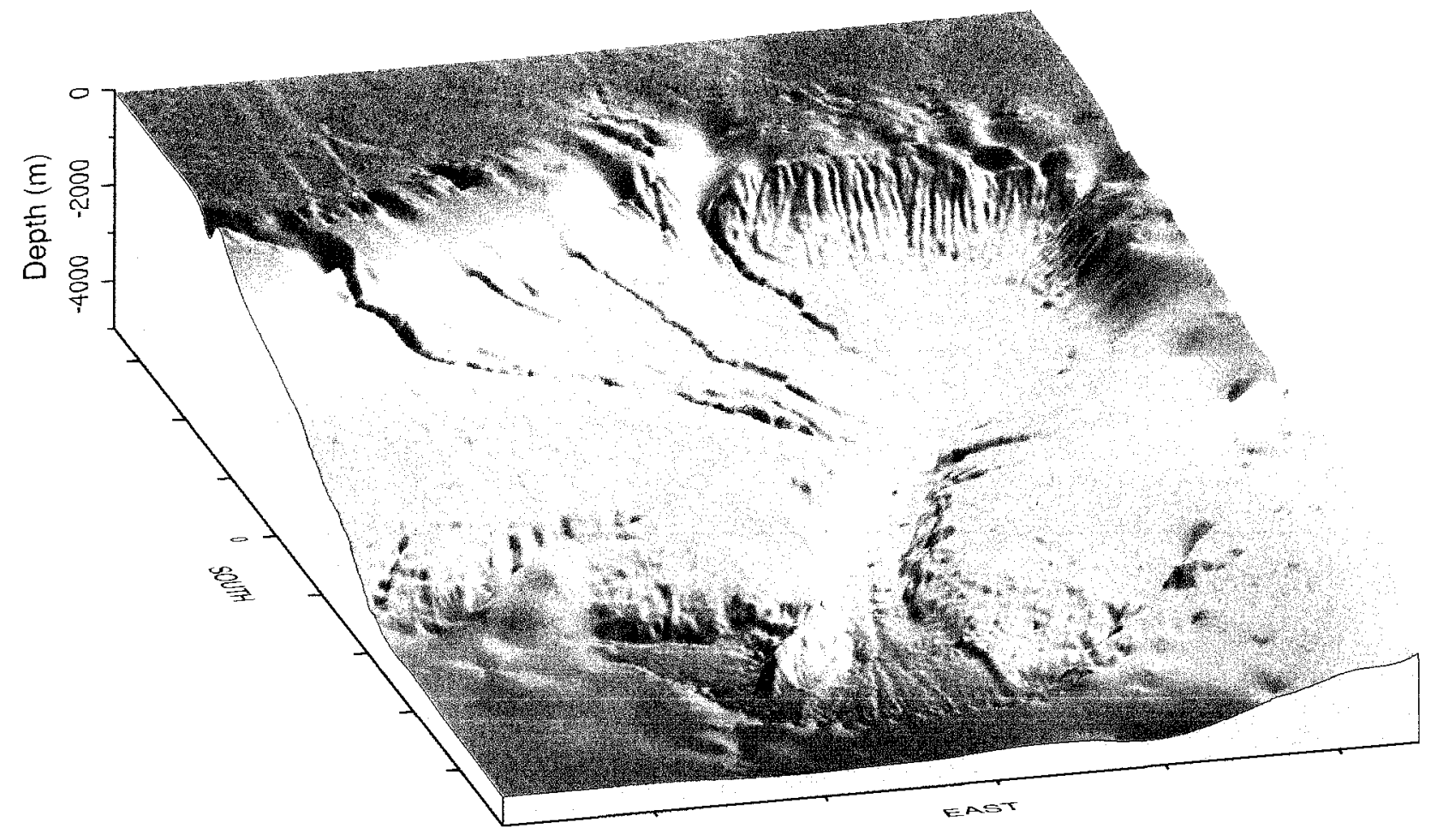

FIG. 6 - Perspective view of Bass Canyon, looking northwest from the Tasman Sea (after Hill et al. 1998). Horizontal scale is indicated by the tick marks at $20 \mathrm{~km}$ intervals. The image was generated from high-resolution swath-mapping data, with infill at the edges of the image provided by older, conventional bathymetric data from multiple sources. The water depths range from about $4400 \mathrm{~m}$ in the Tasman Basin, in the foreground, to less than $200 \mathrm{~m}$ deep on the continental shelf, in the background.

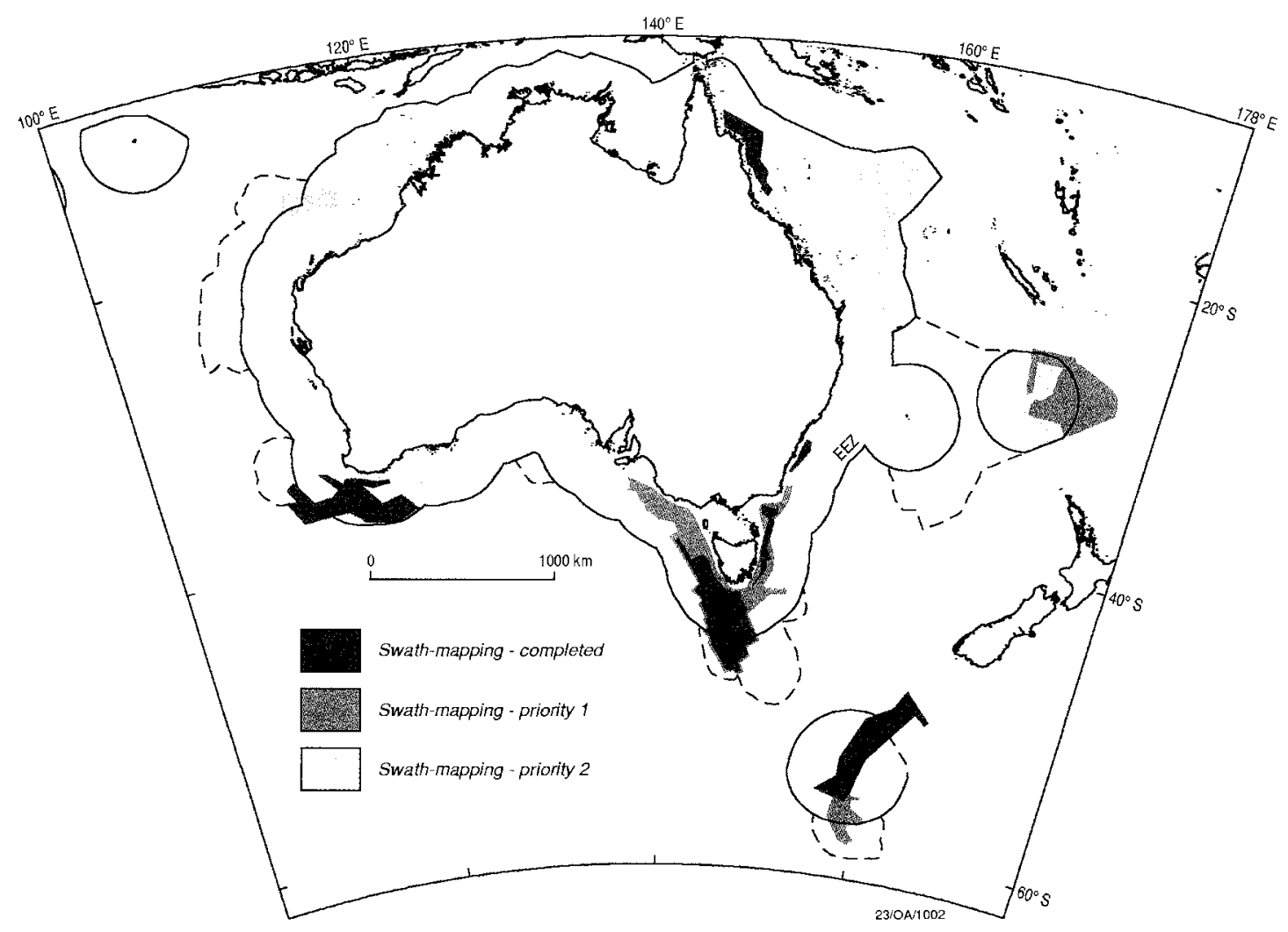

FIG. 7 - Areas around Australia which have previously been swath-mapped, and priority areas for future swath-mapping. 
Howe Rise: The region also contains important commercial and recreatonal fisheries, for which bathymetric and substrate information will be valuable to the determination of habitats and bio divirsity. Australia's major industrial and population concentrations are also located in southeast Australia; urban and rural discharge and water/sediment quality are therefore major issuis, particularly on the continental shelf.

\section{Three Kin}

The exten of the Legal Continental Shelf beyond the EEZ around Nofolk Island is uncertain. Bathymetric data may well enable Australia's claim in this complex area to be considerably extended. This work is now scheduled to be carried out in late 1999, using the French research vessel L'Atalante.

\section{Macquarie Ridge}

The extent of the Legal Continental Shelf south of Macquarie Island along the Macquarie Ridge remains to be defined; detailed bathymetric data are sufficient to establish this claim. In addition, as detailed bathymetry data ate required to assist in the definition of the Macquarie Marine Protected Area $(M P A)$, there is a requirement to fill in the gaps that were left after the 1994 swath-mapping survey.

\section{Southwest Australia}

The tectonic fabric of this area, which is readily apparent in bathymetric data because of the thin surficial sediment cover, is one of the keys to understanding the formation of Australia's southern margin, with consequent impacts for petroleum exploration in the frontier basins of the region, from the southern Perth Basin, through the Great Australian Bight to the Otway Basin. The work required here will complement the cooperative French-Australian MARGAU survey, which was carried out in 1998. Swath-mapping of the upper slope also has the potential to provide information of value to commercial fisheries in the region.

[Since this paper was written, most of the Priority 1 areas have been surveyed by swath-mapping. In late 1999-early 2000 , surveys were carried out in the following areas: northeast Lord Howe Rise; Three Kings Rise/Norfolk Basin; the environs of Lord Howe Island; Macquarie Ridge and southeast Australia (extension and infill of previous surveys); and the Benthic Protection Area in the central Great Australian Bight.]

\section{Priority 2}

\section{Norfolk Ridge}

Norfolk Ridge is a component of the major oceanic plateau, ridge and basin system that was attached to eastern Australia until the mid-Cretaceous. Swath-mapping of the region should enhance our limited understanding of the tectonic fabric of the Lord Howe Rise region, a major area of medium- to long-term hydrocarbon potential. Potential fish habitats and biodiversity in this region are almost entirely unknown.

\section{Mellish Rise/Kenn Plateau}

The Mellish Rise and Kenn Plateau, at the northern end of the Lord Howe Rise, are almost unknown geologically. Swath-mapping of the region will provide geological framework information which has direct relevance to any assessment of the hydrocarbon potential of the northern Lord Howe Rise and northeast Australia.

\section{Exmouth/Scott Plateau margins}

Swath-mapping of the margins of the Exmouth and Scott Plateaus, adjacent to the North West Shelf, Australia's premier hydrocarbon province, will provide new framework information that will lead to an improved understanding of the region.

The Marine Science and Technology Plan recognised that a program to systematically map the shape and form of the seabed in the AMJ would necessarily be a long-term effort. Based on a sea-going effort of 100 days per annum and an average coverage rate of $6000-7000 \mathrm{~km}^{2}$ per day, it is estimated that it would take 15 years to map all off-shelf areas of the AMJ. To this would be added the extra time needed to carry out the seabed sampling required to ground truth these data; this is estimated at a further 30 days per annum. However, systematic mapping of the geomorphic shelf is a much slower process, by virtue of the smaller swath width and average daily coverage of $200-300 \mathrm{~km}^{2}$. A single system operating for 300 days per annum would take at least 30 years to complete coverage of this region. As it is unlikely that multiple vessels are likely to be deployed on this task, it is probable that the morphologic shelf will be surveyed on a priority basis, concentrating initially on the highest use or most environmentally vulnerable areas.

\section{CONCLUSIONS}

While ownership of offshore resources provided under the United Nations Convention on the Law of the Sea bestows certain rights (including the right to exploit resources), it also carries a range of obligations. There is a key national need for Australia to acquire certain basic data sets that can then be made available to all organisations and inviduals working in the marine environment in order to meet these obligations. These needs have been laid out in the Commonwealth's Oceans Policy and in the companion Marine Science and Technology Plan.

The most critical of the baseline data sets is the detailed depth and form of the seafloor, and the nature of the shailow substrate, particularly in high-use areas. Such information underpins the activities of virtually all government, industry and academic sectors working offshore. Knowledge of the seabed is also critical to the issues of multiple sequential land use throughout the Australian Marine Jurisdication. The current state of such knowledge is extremely variable, with adequate information only being available for about $5 \%$ of Australia's offshore. However, with the release of the Oceans Policy, there is now an acknowledgement in the Australian marine community that systematic and prioritised collection of seabed data is in the national interest.

\section{ACKNOWLEDGEMENTS}

We wish to thank Jim Colwell, Barry Willcox and two anonymous reviewers for their constructive comments on this manuscript. This paper is published with the permission of the Chief Executive Officer, Australian Geological Survey Organisation. 


\section{REFERENCES}

Barnes, D.J. \& Lough, J.M., 1989: The nature of skeletal density banding in scleractinian corals: fine banding and seasonal patterns. J. Exploratory Mar. Biol. Ecol. 126: 119-134.

Coffin, M.F., Karner, G.D. \& Falvey, D.A., 1994: Research cruise yields new details of Macquarie Ridge Complex. EOS, Trans. Am. Geophys. Union 75: 561-564.

COMMONWEALTH OF Australia, 1998: AUSTRALIA'S OCEANS POLICY. Environment Australia, Canberra: $48 \mathrm{pp}$.

EXon, N.F. \& Crawford, A.J. (Guest Eds), 1997: West Tasmanian margin and offshore plateaus: geology, tectonic and climatic history, and resource potential. Aust. J. Earth Sci. Thematic Issue 44(5): 539-710.

Exon, N.F. \& HiLL, P.J., 1999: Seabed mapping using multibeam swath-mapping systems: an essential technology for mapping Australia's margins. AGSO J. Aust. Geol. \& Geophys. 17(5/6): 1-16.

Exon, N.F., Hill, P.J., Royer, J.-Y., Muller, D., Whitmore, G., Belton, D., Dutkiewicz, A., Ramel, C., Rollet, N. \& Wellington, A., 1994: Tasmante swath-mapping and reflection seismic cruise off Tasmania using RV L'Atalante. AGSO Cruise 125 report. Aust. Geol. Surv. Org. Rec. 1994/68.

Exon, N.F., Royer, J.-Y. \& Hill, P.J., 1996: Tasmante cruise: swath-mapping and underway geophysics south and west of Tasmania. Mar. Geophys. Res. 18: 275-287.

Exon, N.F., Moore, A.M.G. \& Hill, P.J., 1997; Geological framework of the South Tasman Rise, south of Tasmania, and its sedimentary basins. Aust. J. Earth $S_{c i}$. Thematic Issue 44 (5): 561-577.

Exon, N.F., Hrll, P.J., KeEne, J.B. \& SMith, S.M., 1999: The Sojourn 7 research cruise off eastern Tasmania and in the Gippsland Basin, using R.V. Melville equipped with Seabeam 2000 swath-mapping system. Aust. Geol. Surv. Org. Rec. 1999/7.

Flemming, B.W., 1976: Side-scan sonar: a practical guide. Int. Hydrogr. Rev. 53: 65-92.

Gardner, J.V., Field, M.E., Lee, H., Edwards, B.E., Masson, D.G., KenYon, N. \& KiDD, R.B., 1991: Ground-truthing $6.5 \mathrm{KHz}$ side scan sonagraphs: what are we really imaging? J. Geophys. Res. 96(B4): 5955-5974.

Harris, P.T., Howard, W., O'Brien, P.E., Sedwick, P.N. \& SIKES, E.L., 1999a: Quaternary Antarctic ice-sheet fluctuations and Southern Ocean palacoceanography: natural variability studies at the Antarctic CRC. $A G S O$ J. Aust. Geol. \& Geophys. 17(5/6): 105-119.

Harris, P.T., O'Brien, P.E., Quilty, P., McMinn, A., Holdway, D., Exon, N., Hill, P. \& Wilson, C.W., 1999b: Sedimentation and continental slope processes in the vicinity of an ocean waste disposal site, southeastern Tasmania. Aust. J. Earth Sci. 46(4): 577-591.

Hill, P.J., EXon, N.F. \& RoYeR, J.Y., 1995: Swath-mapping the Australian continental margin: results from offshore Tasmania. Explor. Geophys. 26: 403-411.

Hill, P.J., Exon, N.F., Royer, J-Y., WhitMore, G., Belton, D. \& WELLINGTON, A., 1997: ATLAS OF THE OFFSHORE TASMANIAN REGION: SWATH-MAPPING AND GEOPHYSICAL MAPS FROM AGSO'S 1994 TASMANTE SURVEY. Australian Geological Survey Organisation, 14 map sheets.

Hill, P.J., Exon, N.F., Keene, J.B. \& SmiTh, S.M., 1998: The continental margin off east Tasmania and Gippsland: structure and development using new multibeam sonar data. Explor. Geophys. 29: 410-419.
JENKINS, C.J., 1997: Building a national scale offshore soils database from both word-based and numeric datasets. Sea Technol. 38 (12): 25-28.

Jenkins, C.J. \& Lawrence, M.W., 1990: Report on the RANMarconi GLORIA survey of the EAXA: Continental margin of southeastern Australia. Unpubl. tech. rep. 22, Univ. Sydney Ocean Sci. Inst.: 1-17.

Jenkins, C. \& Searie, B., 1997: A database/GIS of Australian offshore soils. THIRD AUSTRALIAN HYDROGRAPHIC SYMPOSHM PAPERS. Hydrogr. Soc. Spec. Publ. 38 : 164.

Johnson, D.P., Hughes Clarke, J.E. \& von der Borch, C.C., 1992: DEPOSITIONAL SYSTEMS OF TROUGHFILLING SEAWARD OF THE GREAT BARRIER REEF. FIRST AUST'RALIAN MARINE GEOSCIENCE MEETING. Abstracts volume. Australian National University.

Koszow, J.A., 1997: Conservation of seamount fisheries and benthic habitat: the Australian experience. MARINE BENTHIC HABITATS CONFERENCE, NOUMEA. Abstracts. SOPAC, Fiji: 65.

Kostow, J.A. \& Exon, N.F., 1995 - Seamount fisheries prompt calls for exploration and conservation. Aust. Fish. 54 (2): $10-13$.

Marine Science and Technology Plan (MSTP) Working Group, 1998: Australia's Marine Science and Technology Plan draft for consultation. Department of Industry, Science \& Tourism: 96 pp.

Marine Science and Technology Plan (MSTP) Working Group, 1999: Australia's Marine Science and Technology Plan. Department of Industry, Science \& Resources: $146 \mathrm{pp}$.

McCulloch, M.T., Gagan, M.K., Mortimer, G.E., Chivas, A.R. \& Isdale, P.J., 1994: A high resolution $\mathrm{Sr} / \mathrm{Ca}$ and $\delta^{18} \mathrm{O}$ coral record from the Great Barrier Reef, Australia, and the 1982-1983 El Nino. Geochim. Cosmochim. Acta 58(12): $2747-2754$.

Nees, S., Jellinek, T., Suhonen, J., Winkler, A., Helmke, J., Emmermann, P. \& Shipboard SCientific Party, 1998 : IMAGES III - iphis Indian and Pacific Ocean Pleistocene and Holocene history - Cruise MD 106 Leg 1.2 RV Marion Dufresne Hobart (Australia) Christchurch (New Zealand), May 6 to May 21, 1997. Unpubl. preliminary cruise report: $19 \mathrm{pp}$.

ODP, 1996: UNDERSTANDING OUR DYNAMIC EARTH THROUGH OCEAN DRILLING: OCEAN DRILLING PROGRAM LONG RANGE PLAN. Ocean Drilling Program, Washington, DC: $79 \mathrm{pp}$.

Royer, J-Y., Hill, P.J., Beslier, M-O., Exon, N.F., Buchanan, C. \& STAGG, H.M.J., 1998: Seafloor mapping southwest of Australia: the French-Australian MARGAU project. Geol. Soc. Aust. Abstr. 49: 383.

Stagg, H.M.J., Exon, N.F., Colwell, J.B., Symonds, P.A., Heggie, D., Hill, P.J. \& Willcox, J.B., 1997: Report of the planning workshop on a marine geoscience mapping program in the Australian ocean territory. Aust. Geol. Surv. Org. Rec. 1997/18.

Symonds, P.A., \& Wilicox, J.B., 1989: Australia's petroleum potential in areas beyond an Exclusive Economic Zone. BMR J. Aust. Geol. Geophys. 11: 11-36.

von der Borch, C.C. \& Hughes Clarke, J.E., 1993: Slope morphology adjacent to the cool-water carbonate shelf of South Australia: GLORIA and Seabeam imaging. Aust. J. Earth Sci. 40: 57-64.

(accepted 13 October 1999) 